\title{
Impact of Traffic and Customer Switching Behavior of Hinterland Region on the Patimban Port Development
}

\author{
Laurenzo Kansil ${ }^{1}$, Arif Fadillah ${ }^{1 *}$ \\ ${ }^{1}$ Department of Naval Architecture Darma Persada University, Jakarta 13450, Indonesia. \\ ${ }^{*}$ Corresponding author. Email: ariffadillah@ftk.unsada.ac.id
}

\begin{abstract}
Currently, the Government of Indonesia is developing an international standard port in the Patimban area, Subang and it is hoped that this port can reduce export-import density at the Tanjung Priok Port. This final project aims to determine the customer switching behavior in the hinterland area if the Patimban Port operates and analyze the impact of traffic leading to the Tanjung Priok Port and to the Patimban Port due to the influence of customer switching behavior. This final project was carried out by collecting data in the form of a questionnaire and direct data from the relevant agencies. As a result, the construction of the Patimban Port has an influence on Customer Switching Behavior for container service users in the hinterland area. There are several factors that influence consumers to switch, among others, as many as 7 respondents chose the attractiveness of competitors, 4 respondents chose the main service failure, and 3 respondents chose the service and price failure. Then, the influence of Customer Switching Behavior has an impact on traffic leading to the Ports of Tanjung Priok and Patimban. Traffic on the JORR 1 and Inner City Toll Roads experienced a decrease in congestion with DJ values of 0.698 and 0.650, but on the Cikopo and Jomin roads there was an increase with DJ values of 1.33 and 1.26 on weekdays, 1.72 and 1.52 . on weekends.
\end{abstract}

\section{Keywords: Traffic impact, Customer switching, Hinterland, Road congestion}

\section{INTRODUCTION}

In the 2015-2018 period, the average container export and import activity at Tanjung Priok Port was 6.6 million TEUS's (Twenty Feet Equivalent Units) per year and always increasing every year. The increase in exportimport activities in the Tanjung Priok Port area has a negative impact, including increasing the level of congestion that occurs in DKI Jakarta. Based on the 2019 Tomtom Traffic Congestion Ranking, Jakarta ranks 10th out of all cities in the world with the highest congestion rate of 53\%[1]. In addition, ship visits from abroad and domestically at Tanjung Priok Port always increase every year. In the period 2009-2012, the average number of ship visits was 17,000 units[2]. Compared to other major ports in Indonesia, namely the Port of Tanjung Perak, Surabaya. In the period 2009-2013, the average number of ship visits was 14,000 units[3]. This shows that Tanjung Priok Port is the busiest port in Indonesia.

Currently, the Indonesian government is building a new international standard port in the Patimban area, Subang Regency, West Java. The construction is targeted for completion in 2027 with a capacity of 7.5 TEUs
(Twenty Feet Equivalent Units)[4]. This port was prepared by the government to become the largest port on the east side of Jakarta and to support Tanjung Priok Port, Jakarta in serving export and import activities [5].

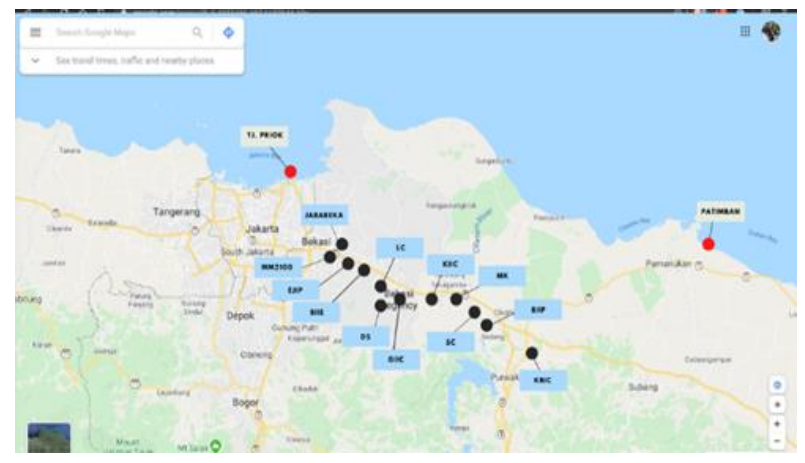

Figure 1. Hinterland Map In the 2015-2018 period

With the new port, it will provide options for container service users in determining a good port as an intermediary facility for the delivery of products/goods that 
will be sent by ship. Therefore, the purpose of this study is to determine the switching behavior of customers in remote areas if Patimban Port operates and analyze the impact of traffic leading to Tanjung Priok Port and Patimban Port as a result of the influence of customer switching behavior.

The method used in this study uses quantitative description by distributing questionnaires to companies that use containers in determining customer switching behavior, while in calculating the impact of traffic using the Indonesian Road Capacity Guidelines (PKJI 2014)[6] based on data from Jasamarga Tollroad Operators, and PT. Hutama Karya - Tanjung Priok Access (PT. Hutama Karya - ATP), PT. Citra Marga Nusaphala and the journal Japan International Cooperation Agency (JICA). The results of this study indicate that the estimated number of container flows always increases every year, in 2020 by 7 million TEU'S and in 2036 by 30.9 TEU'S. That way, according to the provisions, Tanjung Priok Port will experience a saturation point in 2025 with a YOR value of $75.90 \%$ if referring to the Director's Circular Letter or in 2034 with a YOR value of $65.68 \%$ based on the Tanjung Priok Port Authority Regulation. With these problems, it is possible for customers to have the desire to move to Patimban Port. This is indicated by the results of the questionnaire, namely 7 respondents chose competitor attractiveness factors, 4 respondents chose main service failure, and 3 respondents chose service and price failure. Then, the impact that occurs due to customer movement is the level of traffic density in the Jakarta area and in the Patimban area. Based on the results of the study, it was shown that the JORR 1 and Inner City Toll Roads experienced a decrease in congestion with DJ values of 0.698 and 0.650 , but on the Cikopo and Jomin roads there was an increase with DJ values of 1.33 and 1.26 on weekdays, 1.72 and 1.26 , and 1.52 on weekends.

\section{METHODS}

The method used in determining Customer Switching Behavior in this study is quantitative descriptive method by giving questionnaires to companies that use containers in the hinterland areas of Jakarta and Patimban. The questionnaires distributed in this study are closed, where the answers to the questions provided have been provided by, so that respondents can answer questions according to the answer choices provided by the researcher[7]. This questionnaire contains company profiles, assessment of Tanjung Priok Port, and customer answers. Regarding the factors that affect the change of place from the Tanjung Priok Port to the Patimban Port, if the Patimban Port is officially operational. Meanwhile, to determine the impact of traffic density that leads to
Tanjung Priok Port and Patimban Port due to the influence of Customer Switching Behavior, the value of the Degree of Saturation is calculated according to the Indonesian Road Capacity Guidelines (2014)[6]. Traffic data in the Jakarta area were obtained from several toll road management companies, including Jasamarga Tollroad Operator, and PT. Hutama Karya - Tanjung Priok Access (PT. Hutama Karya - ATP), PT. Citra Marga Nusaphala, while for the Patimban area, was obtained based on JICA. There are several main characteristics of the road segment in obtaining the Degree of Saturation (DJ) value, including geometry, separation of traffic directions and composition, traffic flow volume, and road segment capacity.

In calculating the volume of traffic flow using a comparison unit for vehicles in Indonesia, namely the Passenger Car Unit (PCU) which is determined based on the Indonesia Highway Capacity Manual (IHCM). The traffic volume calculation formula is as follows:

$$
Q=\frac{n}{t}
$$

where

$\mathrm{Q}=$ Traffic volume (pcu/jam)

$\mathrm{n}=$ Number of vehicles (pcu)

$\mathrm{t}=$ Vehicle travel time (hour)

The capacity of the road segment is the maximum current that passes through a road per unit hour that can be maintained under certain conditions. Capacity is defined as two-way flow (two-way combination) if the road has two two-way lanes. As for roads that have many lanes, capacity is defined per lane. Capacity is determined based on the following equation formula:

$$
\begin{array}{ll} 
& C=C_{0} x F C_{L J} x F C_{P A} x F C_{H S} x F C_{U K} \\
C & =\text { Capacity (lvu/hour) } \\
C_{0} \quad=\text { Base speed (lvu/hour) } \\
F C_{L J} \quad=\text { Capacity adjustment factor related to lane } \\
\text { width } \\
F C V_{P A}=\text { Capacity adjustment factor regarding direction } \\
\text { separation, only on the undivided path } \\
F C_{H S}=\begin{array}{l}
\text { Capacity adjustment factors related to Side Bar- } \\
\text { riers on shoulder roads }
\end{array} \\
F C_{U K} \quad \text { = Capacity adjustment factor related to city size }
\end{array}
$$

The main measure in determining the performance level of the road segment is determined based on the Degree of Saturation $\left(D_{J}\right)$. The value of $D_{J}$ indicates traffic flow performance and varies from zero to one. The standard value of $D_{J}$ set by PKJI is 0.85 . The $D_{J}$ value equation can be seen based on the formula below: 


$$
D_{J}=\frac{Q}{C}
$$

where:

$D_{J}=$ Degree of Saturation

$\mathrm{Q}=$ Traffic Flow (lvu/hour)

$\mathrm{C}=$ Capacity (lvu/hour)

\section{RESULTS AND DISCUSSION}

\subsection{Container Throughput Projection}

\subsubsection{Tanjung Priok Port, Jakarta.}

The calculation of the container flow projection for Tanjung Priok Port is carried out using the regression method through the Microsoft Excel application program, taking into account the data from previous years[8]. The existing container flows will be projected through simple linear regression which will then be graphed to obtain the exponential equation.

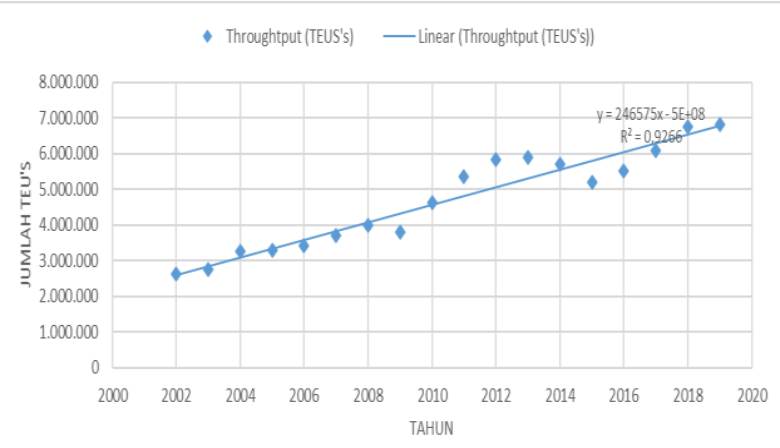

Figure 2. Tanjung Priok port container flow regression chart

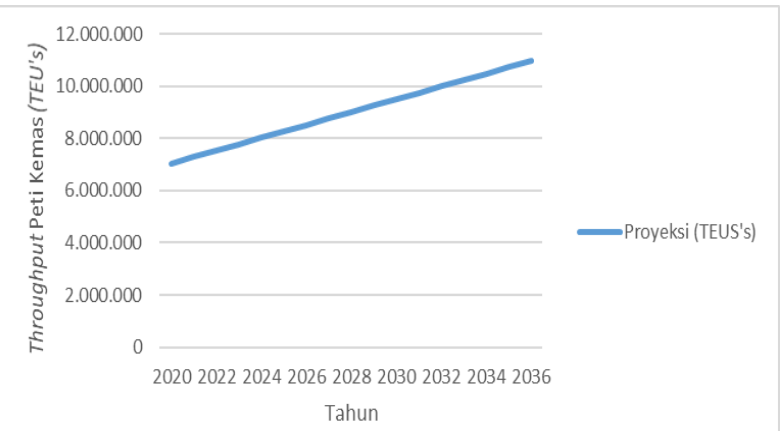

Figure 3. Graph of projected flow of containers at Tanjung Priok port

Based on the graph above, the equation of the exponential function is obtained, namely $\mathrm{y}=246575 \mathrm{x}-$ $5 \mathrm{E}+08$, where $\mathrm{x}$ is the projection year. This exponential equation will be used as a projection calculation in estimating the number of container flows at Tanjung Priok Port in the coming years and the result is that in 2020 the number of container flows is 7 million TEU's and in 2036 the number of container flows at Tanjung Priok Port is of 10.9 Million TEU's.

\subsubsection{Patimban Port, Subang.}

The Patimban Port has been built since 2019 and is estimated to be able to accommodate 350,000 TEU's/year in the first phase of the first phase of development between 2019 -2022. Then, in the 2023-2026 period, in the first phase of the second phase of development, it is estimated that the capacity will increase to 2,858,000 TEU's/year. Patimban Port will carry out the construction of the second phase of the first phase with an estimated additional capacity of 4,122,000 TEU's/year in the 20272029 timeframe. In the second phase of the second phase, which is in the 2030-2036 period, it is estimated that the Patimban Port will complete its construction so that the total container capacity that can be served is $7,380,000$ TEU's[4].

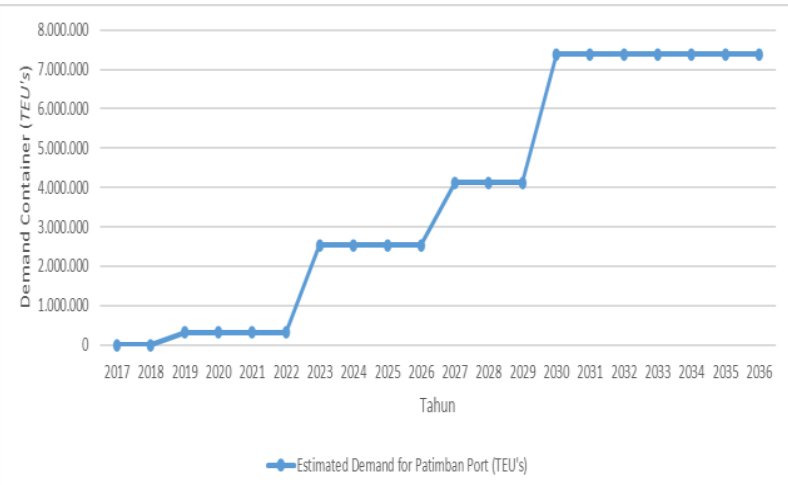

Figure 4. Graph of Demand for Container Flow at Patimban Port.

\subsection{Usage Rate of Container Stacking Field at Tanjung Priok Port}

Based on the Circular of the Director of Pelindo II No: AL.70/1/13/PI.II-10[8], the YOR limit at the container terminal is set at $75 \%$, so that the maximum Dwelling Time (DT) is allowed for containers. Import is 5 days. Meanwhile, based on Tanjung Priok Main Port Authority Regulation No: UM.008/36/4/OP.TPK2018[9], the YOR value limit at the container terminal is set at $65 \%$.

If based on these provisions, the Tanjung Priok Port will experience a saturation point or not the ability to handle container loading and unloading activities in 2025 with a YOR value of $75.90 \%$ if referring to the Circular of the President Director, or in 2034 with a YOR value of $65.68 \%$ based on the Tanjung Priok Port Authority Regulation. 


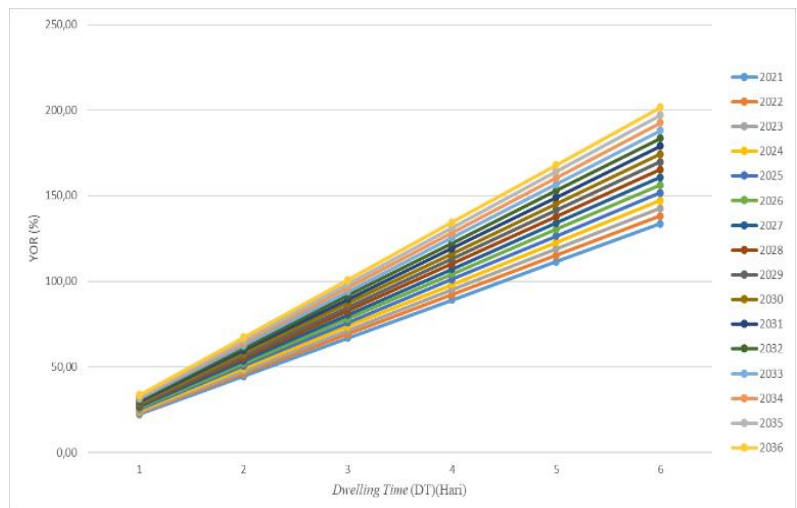

Figure 5. Yard Occupancy Ratio (YOR) Value at Tanjung Priok Port.

\subsection{Costumer Switching Behavior}

In determining the factors that influence customer switching behavior in this study, the authors provide questionnaires to respondents/companies that use container services located in the hinterland, among others, in the Cikarang, Karawang, and Purwakarta areas. The results of the questionnaires that have been distributed and answered by the respondents will determine the customer switching behavior in this study.

Based on the percentage of introduction to Patimban Port, there are $47.6 \%$ of the total respondents who do not know about Patimban Port, while another 52.4\% know about Patimban Port. The difference in percentage that is not large enough indicates that there is very little information about the Patimban Port for these companies. So the answers from these companies are more likely to choose "No". Meanwhile, based on the presentation of customer displacement from 22 respondents who answered the questionnaire, there were 6 respondents or about $27.3 \%$ of the total respondents who wished to move if Patimban Port was operating, while 16 respondents or around $72.7 \%$ of the total respondents did not have the desire moved to Patimban Port.

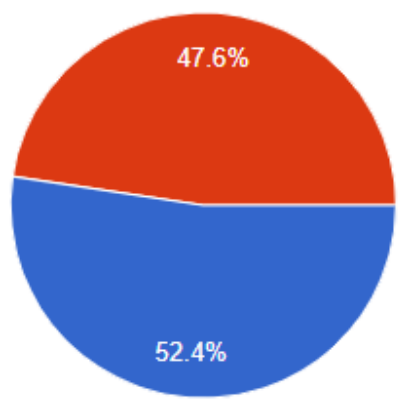

Figure 6. Percentage of Introduction to Patimban Port for Respondents.

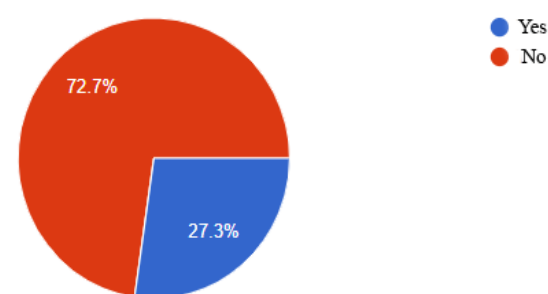

Figure 7. Customer Transfer Percentage

This shows that Tanjung Priok Port is still the main choice of respondents in choosing container services. In addition, if it is associated with respondents' answers regarding information about the existence of Patimban Port, the percentage of respondents' answers who do not know about Patimban Port is $47.6 \%$, there is a possibility that this is one of the reasons why respondents' desire to move to Patimban Port is still low, which is only $27.3 \%$. . However, it is possible that more and more respondents will move to the Patimban Port if it is operational, if you look at some of the respondents' answers to the factors that affect the displacement as shown in the graph below.

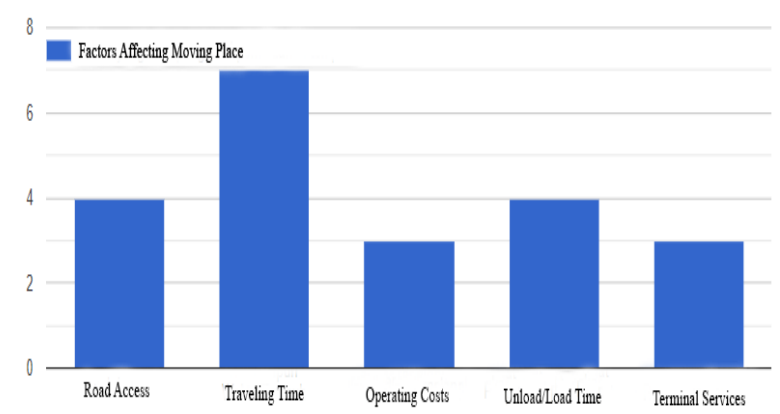

Figure 8. Factors Affecting Moving Place.

If you look at the conclusions above, in Figure 8 the most dominant cause of customer switching behavior is the competitor's attractiveness factor which is marked by respondents' responses to the issue of travel time with the number of respondents who chose as many as 7 respondents. In addition, what affects customer switching behavior in this study is the main service failure factor marked by responses to road access factors and loading/unloading times amounting 4 respondents. Then, what affects the next customer switching behavior is the service failure factor marked by the responses to the terminal service factor totaling 3 respondents and the last is the price factor marked by the respondents' responses to the operational cost factor totaling 3 respondents. 
Table 1. Value of Degree of Saturation (DJ) Jakarta Outer Ring Road Toll Road.

\begin{tabular}{|l|c|c|c|}
\hline \multirow{2}{*}{ Direction } & Capacity C & Traffic Flow $Q$ & \multirow{2}{*}{ Degree of Saturation DJ } \\
\cline { 2 - 3 } & (LVC/hour) & 652 & 0,388 \\
\hline To Tanjung Priok & 1.682 & 552 & 0,328 \\
\hline To Tanjung Priok & 1.682 & 744 & 0,443 \\
\hline (Moving Truck) & 1.682 & 622 & 0,37 \\
\hline To Cikampek & 1.682 & 1.396 & 0,83 \\
\hline To Cikampek & 1.682 & 1.174 & 0,698 \\
\hline (Moving Truck) & 1.682 & & \multirow{2}{*}{ (LV) } \\
\hline Both directions & & & \\
\hline (Moving Truck) & & & \\
\hline
\end{tabular}

\subsection{Road Traffic Performance Level}

Research on toll road sections is carried out based on data obtained from several toll road operators including vehicle data and road segment data.

\subsubsection{Jakarta Outer Ring Road Toll Road (JORR.)}

Based on Table 1, the traffic performance on the Jakarta Outer Ring Road toll road section is declared good, because the value of the Degree of saturation on both roads has decreased when the container truck changed its destination from Tanjung Priok Port to Patimban Port with an initial DJ value of 0.830 decrease to 0.698 .

\subsubsection{Jakarta Inner Ring Road.}

Table 2. The Value of Degree of Saturation (DJ) In Jakarta Inner Ring Road.

\begin{tabular}{|c|c|c|}
\hline \multirow{2}{*}{ Direction } & Before & After \\
\cline { 2 - 3 } & $\begin{array}{c}\text { Degree of } \\
\text { Saturation }\end{array}$ & $\begin{array}{c}\text { Degree of Sat- } \\
\text { uration }\end{array}$ \\
\cline { 2 - 3 } & $D_{J}$ & $D_{J}$ \\
\hline To Port & 0,61 & 0,68 \\
\hline From Port & 0,58 & 0,65 \\
\hline Both Directions & 1,22 & 1,33 \\
\hline
\end{tabular}

Based on Table 2, the Jakarta Inner Ring Road section towards the Jakarta-Cikampek Toll Road has a capacity value of $1,682 \mathrm{skr} / \mathrm{hour}$ and a total value of traffic flow of 1,206 skr/hour. Then the results obtained for the Degree of Saturation is equal to 0.717 . If the container truck moves, the value of the Degree of saturation decreases to 0.650 .

\subsubsection{Cikopo Intersection.}

The Cikopo intersection on weekdays towards the port has a Degree of Saturation of 0.610. If the container truck moves, the value of the Degree of Saturation will increase, which is 0.680. Meanwhile, for the opposite direction from the port direction, the value of the Degree of Saturation is 0.58 , and if the container truck moves the value of the Degree of Saturation will increase by 0.65 . For the total from both directions if the container truck moves it has a Degree of Saturation value of 1.33. Then on weekends, the Cikopo intersection towards the port has a degree of saturatio value of 0.560 . If the container truck moves, the value of the Degree of Saturation will increase, which is 0.620 . Meanwhile, for the opposite direction from the port direction, the value of the Degree of Saturation is 0.57 , and if the container truck moves, the value of the Degree of Saturation will increase by 0.64 . For the total from both directions if the container truck moves it has a Degree of Saturation value of 1.26.

Table 3. The Value of Degree of Saturation (DJ) Cikoo Intersection (Weekday).

\begin{tabular}{|c|c|c|}
\hline \multirow{2}{*}{ Direction } & Before & After \\
\cline { 2 - 3 } & $\begin{array}{c}\text { Degree of } \\
\text { Saturation }\end{array}$ & $\begin{array}{c}\text { Degree of Sat- } \\
\text { uration }\end{array}$ \\
\cline { 2 - 3 } & $D_{\lrcorner}$ & $D_{J}$ \\
\hline To Port & 0,56 & 0,62 \\
\hline From Port & 0,57 & 0,64 \\
\hline Both Directions & 1,15 & 1,26 \\
\hline
\end{tabular}


Table 4. The Value of Degree of Saturation (DJ) Cikopo Intersection (Weekend).

\begin{tabular}{|l|c|c|c|}
\hline \multirow{2}{*}{ Direction } & Capacity C & Traffic Flow Q & $\begin{array}{c}\text { Degree of Saturation } \\
\text { DJ }\end{array}$ \\
\cline { 1 - 3 } & (LVC/hour) & (LVC/hour) & 0,388 \\
\hline To Tanjung Priok & 1.682 & 652 & 0,328 \\
\hline To Tanjung Priok & 1.682 & 552 & 0,443 \\
\hline To Cikampek & 1.682 & 744 & 0,37 \\
\hline To Cikampek & 1.682 & 622 & 0,83 \\
\hline (Moving Truck) & 1.682 & 1.396 & 0,698 \\
\hline Both directions & 1.682 & 1.174 & \multirow{2}{*}{} \\
\hline (Moving Truck) & & & \\
\hline
\end{tabular}

\subsubsection{Jomin Intersection.}

On weekdays, the Jomin intersection towards the Port has a Degree of Saturation value of 0.84. If the container truck moves, the value of the Degree of Saturation will increase by 0.86 . Meanwhile, for the opposite direction from the port direction, the value of the Degree of Saturation is 0.84 , and if the container truck moves, the value of the Degree of Saturation will increase by 0.87 . Then on weekends, the Jomin Intersection towards the Port has a Degree of Saturation value of 0.69. If the container truck moves, the value of the Degree of Saturation will increase by 0.71 . Meanwhile, for the opposite direction from the port direction, the value of the Degree of Saturation is 0.78, and if the container truck moves, the value of the Degree of Saturation increases by 0.81 . For the total from both directions if the container truck moves it has a Degree of Saturation value of 1.52

Table 5. The Value of Degree of Saturation (DJ) Jomin Intersection (Weekday).

\begin{tabular}{|c|c|c|}
\hline \multirow{2}{*}{ Direction } & Before & After \\
\cline { 2 - 3 } & $\begin{array}{c}\text { Degree of } \\
\text { Saturation }\end{array}$ & $\begin{array}{c}\text { Degree of Sat- } \\
\text { uration }\end{array}$ \\
\cline { 2 - 3 } & $D J$ & $D J$ \\
\hline To Port & 0,84 & 0,86 \\
\hline From Port & 0,84 & 0,87 \\
\hline Both Directions & 1,62 & 1,72 \\
\hline
\end{tabular}

Table 6. The Value of Degree of Saturation (DJ)

\begin{tabular}{|c|c|c|}
\hline \multirow{2}{*}{ Direction } & Before & After \\
\cline { 2 - 3 } & $\begin{array}{c}\text { Degree of } \\
\text { Saturation }\end{array}$ & $\begin{array}{c}\text { Degree of Sat- } \\
\text { uration }\end{array}$ \\
\cline { 2 - 3 } & $D_{\lrcorner}$ & $D_{J}$ \\
\hline To Port & 0,69 & 0,71 \\
\hline From Port & 0,78 & 0,81 \\
\hline Both Directions & 1,42 & 1,52 \\
\hline
\end{tabular}

\section{CONCLUSION}

According to the analysis of container throughput at Tanjung Priok Port, it shows that container demand will continue to increase, and Tanjung Priok Port will experience a saturation point in 2025 , referring to the Circular of the President Director, or in 2034 with a YOR value of $65.68 \%$ based on the Port Authority Regulation. Tanjung Priok. So with that, Patimban Port is a supporting solution for Tanjung Priok Port in export-import activities.

Based on the estimated saturation point, there is an impact that arises, namely the desire to move customers from Tanjung Priok Port to Patimban Port. This can be seen from the factors that influence it, among others, the attractiveness of competitors as indicated by the answers to the questionnaire as many as 7 respondents, the main service failure factor with 4 respondents, and the service failure factor and price with 3 respondents.

In addition, the impact that arises if the customer moves to the Patimban Port is that the traffic density on the Jakarta Outer Ring Road and Jakarta Inner Ring Road has decreased with the marked value of the Degree of Saturation $\left(D_{J}\right)$ being below the stipulation value $\left(D_{J}>\right.$ 0.85 ), namely of 0.698 on the JORR I Toll Road and 0.65 on the Jakarta Inner Ring Road, while for roads at the intersection of Cikopo and Jomin during weekdays and weekends, it has increased due to the displacement of the destination of container trucks with the marked value of the Degree of Saturation $\left(D_{J}\right)$ being above the specified value ( $D_{\mathrm{J}}>0.85$ ) which is 1.33 and 1.26 at the Cikopo intersection and 1.72 and 1.52 at the Jomin intersection.

In overcoming the increasing congestion in the area of the Cikopo and Jomin Intersection Roads directly following the flow of containers to the Patimban Port, a good solution is to build a toll road access to the Patimban Port and the construction of a container railway to 
the Patimban Port. Then, further research is needed to determine the impact of traffic at Tanjung Priok and Patimban ports after the toll roads and trains to Patimban Port have operated.

\section{REFERENCES}

[1] Tomtom2019 Traffic Index 2019 Tomtom.com

[2] Fadillah A 2014 KAJIAN EMISI GAS BUANG DARI KAPAL DI PELABUHAN TANJUNG PRIOK Pros. Semin. Has. Penelit. SEMESTER GANJIL 2013/2014 Univ. DARMA PERSADA 277-88

[3] Fadillah A, Pusaka A, Manullang S, Dewanto Y A and Faturachman D 2015 Strategy for Reducing Pollutant Emissions from Ship Activities at the Port of Tanjung Perak, Surabaya WSEAS Trans. Environ. Dev. ISSN / E-ISSN 1790-5079 / 2224-3496 $11155-62$

[4] Japan International Cooperation Agency 2017 The Preparatory Survey on Patimban Port Development Project in the Republic of Indonesia 17-65

[5] Malisan J 2017 Port of Patimban as A Solution to Fulfill the Capacity Demand of Port Terminal in Indonesia Int. J. Innov. Eng. Technol. 8 303-10

[6] PKJI 2014 Pedoman Kapasitas Jalan Perkotaan (PKJI) 70

[7] Sugiyono 2015 Metode Penelitian dan Pengembangan Pendekatan Kualitatif, Kuantitatif, dan R\&D Metod. Penelit. dan Pengemb. Pendekatan Kualitatif, Kuantitatif, dan R\&D 130

[8] Ariyanto D 2019 Pengaruh Depo Lini Dua untuk Mengoptimalkan Waktu Tunggu Tiga Hari di Pelabuhan J. Penelit. Transp. Laut 20109

[9] Perhubungan K 2016 Peraturan Menteri Perhubungan Nomor 116 Tahun 2016 Tentang Pemindahan Barang di Pelabuhan Utama 7 